University of Louisville

ThinkIR: The University of Louisville's Institutional Repository

\title{
Bilingual intercultural education in Ecuador : education as a means of language revitalization.
}

\author{
L Danielle Robinette \\ University of Louisville
}

Follow this and additional works at: https://ir.library.louisville.edu/honors

Part of the Bilingual, Multilingual, and Multicultural Education Commons

\section{Recommended Citation}

Robinette, L Danielle, "Bilingual intercultural education in Ecuador : education as a means of language revitalization." (2015). College of Arts \& Sciences Senior Honors Theses. Paper 35.

http://doi.org/10.18297/honors/35

This Senior Honors Thesis is brought to you for free and open access by the College of Arts \& Sciences at ThinkIR: The University of Louisville's Institutional Repository. It has been accepted for inclusion in College of Arts \& Sciences Senior Honors Theses by an authorized administrator of ThinkIR: The University of Louisville's Institutional Repository. This title appears here courtesy of the author, who has retained all other copyrights. For more information, please contact thinkir@louisville.edu. 
Bilingual Intercultural Education in Ecuador:

Education as a means of language revitalization

$$
\text { By }
$$

L. Danielle Robinette

Submitted in partial fulfillment of the requirements for Graduation summa cum laude

University of Louisville

March, 2015 


\section{"Languages are rarely acquired for their own sake. They} are acquired as keys to other things that are desired"

(Fishman 1977: 115).

According to the 2010 Ecuadorian National Census, there are nearly 14.5 million people in Ecuador and, of that number, 7 percent self-identify as 'indígena', or indigenous. However, based on how the question is asked and who is willing to answer, this number varies greatly to reflect as high as 30 percent of the total population (Haboud 2004). Regardless, it is generally accepted that there are an estimated 2.2 million Quichua speakers in Ecuador which includes individuals who learned it as their first, second, or only language. Despite this relatively large number, the language is still classified as developing or threatened depending on regional variety (Paul, et al). In response to the language loss faced by Quichua in Ecuador, various interest groups emerged to combat the diminishing number of speakers; various efforts ranged from grassroots organization to national policy implementation. These efforts reflect a number of different approaches to language revitalization but most prominent is the growth and development of bilingual intercultural education (BIE). While there is extensive discourse debating what BIE should include, or exclude, and whether or not it works, there is minimal discussion about what the term means. Superficially, it could be understood to mean bilingual education that addresses the cultural interaction of the two language groups. However, the meaning of the term 'intercultural' is the most problematic. In an extensive examination of what the word may mean in various contexts, Nancy Hornberger (2000) concludes that for Ecuador it means the one-way implementation of indigenous culture (through Quichua language education) into a predominantly Spanish and Mestizo educational environment (178). With this definition, BIE programs can be understood as those that teach in a bilingual environment that encourages the introduction of indigenous culture into the established social development of students. 
It should quickly be noted that the differentiation between the 'Quechua' language family and the Quichua used in Ecuador reflects the geographic development of the region. Quechua refers to the language established in the Andes region by Incan migrants in the fifteenth century. Quichua refers to the particular varieties of that language used in Ecuador and Argentina (Adelaar 168). It should be clarified that Quichua is not a dialect of Quechua, but rather a different name for the greater language family that is now considered native to the Andean countries. While there are innumerable dialects within the Quechuan family, and there are arguments about their mutual intelligibility, the language as a whole is referred to as Quichua in Ecuador. In fact, the spelling quichua is most likely just a reflection of pronunciation differences between the region of the Incan empire that is now Ecuador and that of Peru, given that the word was first written as a transliteration by the Spanish explorers (179).

Education is only a small part of the greater task of the language planning endeavor which typically includes status (popular perception), corpus (grammar and spelling), and acquisition (teaching and learning) planning. Education falls into the category of acquisition planning, and thus represents just one of many ways in which a country or a people can pursue the revitalization of a language. Linguists argue that choosing just one of such methods would be inadequate to successful reverse language shift and preserve an endangered or dying language. Therefore, it is important to understand BIE as one aspect of a bigger linguistic picture. Using two models designed by Joshua Fishman, this research will attempt to depict the precarious socio-political situation surrounding language shift and revitalization in Ecuador. First is his framework for the classification of appropriate language planning decisions based on a nation's stage of development regarding a unified cultural identity and second is his theory that reversing language shift is a social justice movement. 
Using the above models, this paper will examine the multilingual nature of Ecuador as a political consequence of repeated colonization and will analyze indigenous language revitalization as a social movement seeking to correct centuries of inequality. Specifically, it will discuss BIE programs as one revitalization method employed in Ecuador and will assess their success or failure using standardized assessment scores and the ethnographic fieldwork of Kendall King. While the linguistic situation in Ecuador is unique based on the history of the region, other bilingual intercultural education projects in other parts of the world speak to and reflect the same concerns that have arisen in the Andes. Projects in other contexts will be considered with the intention of analogizing the linguistic environments to the extent possible.

\section{Background}

The linguistic situation in Ecuador is a result of the political history of the region and cannot, therefore, be separated from the political development of the Incan Empire and later of Spanish colonization. In his history of the languages of the Andes, Willem Adelaar (2004) describes how the Incan Empire consolidated and homogenized the region through forced migration and legal subjugation of the native languages to specific social spheres. These changes affected how the region underwent a significant demographic change during the two periods of conquest - first by the Incas in 1450 and then by the Spaniards in 1534. Quechua had gained official status during the end of the Incan administration and thus grew in prominence and importance over the other indigenous languages. Furthermore, the indigenous people of Ecuador were able to continue using Quichua in both the private and public spheres until 1770 Bourbon reforms (167). Ecuador broke from Spain in 1822 and became an independent republic in 1830. Military coups in 1963 and 1972 establish political reform that led to dictatorship until a democratic constitution is adopted in 1979. This constitution is frequently changed with the 
most recent ratification in 2008 and the most recent amendment in 2011 (BBC). Quichua is not the only native language to exist or maintain prominence in Ecuador. But, if the various dialects of Quichua that continue to be used in Ecuador are considered together, Quichua is the language of approximately 15 percent of the national population and represents the largest minority language group in the country.

Ecuador is a now a republic broken into 24 provinces with a President who is both head of state and head of government. They have a three-branch government with executive, legislative, and judicial functions. The executive branch includes 28 ministries led by presidential appointees (CIA Factbook). The Ministry of Education and Culture (MEC) is responsible for guaranteeing access and quality of education at all levels "taking into account the intercultural society, plural nationalities, [and] ancestral languages... in order to strengthen the social, economic, and cultural development... and unity in the diversity of Ecuadorian society"1 Among numerous Ministry goals is that "to increase cultural and linguistic relevance in all levels of the education system"״ (Ministerio de Educación). This goal is central to the tenants of BIE that seeks to weave indigenous language and culture studies into the common classroom environment. In order to implement this goal, the National Directorate of Bilingual Intercultural Education was established under the Sub-Secretary of Bilingual Intercultural Education under the Vice Minister of Education to focus solely on the creation and support of BIE programs in Ecuador.

\footnotetext{
${ }^{1}$ Translation mine: "tomando en cuenta la interculturalidad, la plurinacionalidad, [y] las lenguas ancestrales... para fortalecer el desarrollo social, económico y cultural... y la unidad en la diversidad de la sociedad ecuatoriana".

${ }^{2}$ Translation mine: "Incrementar la pertinencia cultural y lingüística en todos los niveles del sistema educativo".
} 


\section{Language as Identity}

"Men build their cultures by huddling together, nervously loquacious, at the edge of an abyss."

(Burke 1954: 136).

There is something inherent about language as the tool of personal expression that makes it crucial to identity. Society, if defined as the way in which individuals group themselves with others, requires the pursuit of commonalities that draw them together. Language, along with a number of other cultural elements such as literature and history, achieves this end. Some linguists argue that the death of a language brings with it the loss of parts of the cultures with which it comes into contact. Nettle and Romaine (2000) call language a "living museum." Thus, when that museum is lost, the people have lost a part of their cultural history. This understanding connects a population's language with crucial part of their identity in a manner so inextricable that requires the preservation of a language in order to avoid the extinction of a people and their culture. In order to understand the cultural element of bilingual intercultural education, it is important to first understand how language serves as a critical aspect of ethnic and cultural identity, and thus how it can be incorporated into language education.

In her study of the attitudes of various groups in Ecuador regarding the teaching of foreign languages (FL), Marleen Haboud (2009) found that there is a hierarchy of bilingualism. 'Elite bilinguals' are those that speak English, French, or German in addition to Spanish. 'Minoritized bilinguals' are those that speak an indigenous language in addition to Spanish (67). This hierarchy is a reflection of the attitudes that, whether intentionally or not, have defined the socio-linguistic environment in Ecuador. By casting inferiority on those who speak an indigenous language rather than a European language, Ecuador has encouraged a complex among the indigenous peoples who have internalized their inferiority as a part of their identity. 
Haboud notes that "attitudes are intimately tied to symbolic or concrete functions assigned to a language" (68). Symbolic functions are those that contribute to one's sense of belonging or self-identification. Concrete functions are those that make a language a useful tool within society. The former makes one willing to use and preserve a language while the latter convinces one that they must learn a certain language in order to get by in life. While this particular study by Haboud sought to understand the people's motivations, or lack thereof, to teach a foreign language in indigenous schools, her research is also telling of the roles various groups understand languages to have. Her interviews of indigenous and Mestizo groups demonstrate a contrast of opinions regarding the teaching of foreign languages. The indigenous peoples believed that they would need English in order to compete with the Mestizo population in both educational and economic spheres. They argue that English will allow them to keep up with modernization and globalization in Ecuador while protecting them from economic interference from the more urbanized regions. On the other hand, the Mestizo population expressed the opinion that introducing English in indigenous areas would contribute to language and identity loss. Those interviewed from the Mestizo communities articulated the belief that indigenous peoples either did not need to learn a foreign language or were incapable of doing so (70-71). These attitudes reflect the hierarchical understanding of language in Ecuador and demonstrate that Quichua, as an indigenous language, is at the bottom of the pyramid. The stigma attached to Quichua encourages individuals to use Spanish and parents to shy away from indigenous language education for their children.

These reactions demonstrate how the various groups understand each other within the socio-linguistic world in which they interact. The indigenous groups believe they need to be able to protect themselves from the Mestizo population that tend to live in more urban cities and have 
better education, thus allowing them greater access to economic opportunity. One teacher from an indigenous school stated that he thought the teaching of English may help to combat the negative stereotypes that his students suffer. Regardless of ability or desire, Mestizo teachers believe that indigenous schools' time would be better spent reinforcing their native languages and cultures rather than learning English.

While popular perception of Quichua is mixed, there are notable lines of demarcation that speak to who values Quichua and why. On the one hand, across various studies from the 80 s and 90s, it seemed clear that many indigenous parents preferred that their children be educated in Spanish due to the belief that Spanish was more likely to improve their children's economic future. Interviews of the Mestizo population were even harsher, claiming that Quichua is "backward" and "useless." These opinions reflect the belief of the period that first, Quichua was not in danger of being lost, and second, that Spanish held a greater economic (concrete) value. However, some were willing to concede that Quichua held a symbolic value that contributed to ethnic identity (Hornberger \& Coronel-Molina 2004: 14-5). This discourse of the perception of Quichua at the end of the $20^{\text {th }}$ century demonstrated that there was a common understanding of the dichotomy of the economic versus symbolic utility of Quichua in Ecuador. It is important for language planners in any part of the process to be aware of this dual perception when pursuing language policy. Without popular consent and support, policy implementation would be exceedingly difficult, if not impossible. However, as Hornberger and Coronel-Molina (2004) note, Ecuador has seen a growth in support for the cultural and symbolic value of Quichua following the 2000 coup d'état. During the coup, the coalition to oust then President Jamil Mahuad included Antonio Vargas, President of the Confederation of the Indigenous Nationalities of Ecuador, who famously gave a speech entirely in Quichua. They argue that while some in the 
audience likely did not even understand Vargas's speech, that their lack of criticism regarding the choice demonstrates a notion of support of Quichua in the political realm (16). While the dichotomy between concrete and symbolic value continues to exist, the importance placed on cultural significance of Quichua appears to be gaining momentum in the region. This shift will bleed into language planning decisions, particularly as they pertain to BIE.

To the indigenous people, their native language, while potentially maintaining symbolic functions, hinders their ability to compete in education and the economy. Their knowledge and use of Quichua has shaped both how others see them as well as how they see themselves. Their language has not only shaped their identity, but has become a crucial aspect of it. As a result, Quichua education in Ecuador must focus not only on the language itself, but also on the culture from which it developed. In this way, it may be possible to both revitalize the language and preserve the culture. In pursuit of this ideal, the Ecuadorian government has begun to pursue BIE that seeks to further indigenous language and culture in the various regions of the country.

\section{Political Involvement in Quichua Language Planning}

In 1996, the World Conference on Linguistic Rights produced the Universal Declaration of Linguistic Rights in which they advocated for the protection and respect for all languages and their use in private and public spheres. Of the rights and provision enumerated by the Declaration, the right to access to education in one's native language serves to not only preserve, but also grow languages facing endangerment or extinction. In countries like Ecuador where numerous language groups coexist, the government must address bilingual education policy in order to comply with the guidelines set by the Declaration.

Article 2 of Ecuador's 2008 constitution states while Spanish is the nation's official language, Quichua and Shuar are languages for intercultural ties. Moreover it states that "the 
other ancestral languages are in official use by indigenous peoples in the areas where they live and in accordance with the terms set forth by law. The State shall respect and encourage their preservation and use." However, the legal development of this linguistic recognition took nearly three decades. King and Haboud (2002) trace this development beginning with Decree No. 000529 in 1981, which mandated bilingual, intercultural primary and secondary education in areas that were populated predominantly by indigenous peoples. Next, in 1983, the new constitution included Article 27 that required that Quichua be used in schools in these predominantly indigenous zones. However, without a body specifically charged to enforce or encourage these constitutional changes, it would be years before these legal foundations would see any real change take place.

These questions of language education, among other concerns of the indigenous communities, led to the establishment of the Confederation of the Indigenous Nationalities of Ecuador (CONAIE) to be "the representative body that guarantees indigenous people the political voice that has too long been denied them, and that expresses their needs and goals within a rapidly changing world" (CONAIE, 1998). This organization sought to speak for the indigenous communities and lobby on their behalf on issues of concern to them, including language and education programs. In 1989, CONAIE and the Ministry of Education created the Department for Intercultural Bilingual Education (DINEIB) in order to organize the administration of schools covered by the aforementioned legislation regarding education in Quichua (King 2001; 43). With the establishment of DINEIB, the government of Ecuador demonstrated a commitment to the development of pedagogical materials and teacher training, both of which must be present if Quichua language education is to be considered successful (King \& Haboud, 379). DINEIB administration and allocation of resources allowed the earliest 
BIE projects, such as the Intercultural Bilingual Education Project (PEBI) and Shuar Distance Radio Education Systems (SERBISH), to arise in Ecuador and to begin the teaching of native languages (King 2001; 39, 43).

In 1993, the Ministry of Education and Culture (MEC) recognized 'el Modelo del Sistema de Educación Intercultural Bilingüe' (MOSEIB - /Bilingual Intercultural Education Model/) that seeks "to strengthen the quality of education with cultural and linguistic relevance to develop cognitive, psychomotor, and emotional skills and abilities of students of various nationalities and peoples in BIE institutions"3 (MOSEIB). MOSEIB intends to create a family and community model that aligns with Joshua Fishman's (1990) belief that in order for language shift to be successful there must be intergenerational communication reinforcing the classroom work. MOSEIB serves as the actionable measures sought by the MEC in establishing DINEIB as the branch of the Ministry charged with addressing the concerns of bilingual education.

Fishman (1969) establishes a three-tiered framework for classifying developing nations in different stages of language planning. First, there are a-modal nations in which the country chooses a language of wider communication (LWC), usually that of their former western colonial power, in hopes of further political integration and a step into modernity. These nations grow out of the void of a unified socio-cultural identity that might compel them to respond otherwise (113). Next, there are uni-modal nations in which there does exist an established socio-cultural unity, usually that of the precolonial indigenous peoples, and the government uses language planning to preserve and modernize a traditional language (116-7). Finally, there are multi-modal nations in which there is a competition of prominent socio-cultural traditions that must bring language planning to a regional level in order to avoid an interference with questions

\footnotetext{
${ }^{3}$ Translation mine: "fortalecer la calidad de la educación con pertinencia cultural y lingüistica a fin de desarrollar las habilidades y destrezas cognitivas, psicomotores y afectivas de los estudiantes de nacionalidades y pueblos en las instituciones educativas interculturales bilingües".
} 
of national unity. These countries choose to determine official languages at the regional, rather than national, level. While these decisions may appear to be the easiest way to appease a greater number of people, Fishman notes that a country must realize the complications that arise when each language must be modernized for educational purposes (121).

In Ecuador, the country seems to be straddling the line between uni- and multi-modal. If one is just to consider Quichua, Ecuador meets many of Fishman's qualifications of the unimodal nation. There is a prominent indigenous tradition that preceded the colonial imposition of Spanish. The language has been standardized and a literary tradition exists. Language planning decisions have been made to respect people's decision to educate their children in Quichua. However, the greater linguistic context of Ecuador depicts a multilingual nation that may be more suited to the decisions that correspond to a multi-modal nation. The various languages of Ecuador have survived centuries of colonial control at the hands of both the Incas and then the Spanish. With the combination of the multilingual environment and the complicated cultural identities of Ecuador, the framework established by Fishman is made more complicated. However, if given the choice, it appears that the regional decisions appropriate for multi-modal nations would best fit the situation in Ecuador. Given the number of indigenous languages that exist in Ecuador, and the different indigenous cultures from which they arose, the coexistence of these traditions is best fostered in the multi-modal nation model. The question becomes how the government can adapt the political environment to expand upon its current theoretical support of indigenous languages to a more tangible support that will overcome the modernization complications that Fishman predicted 


\section{Codification and Standardization of Quichua}

In their article Authenticity and Unification in Quechua Language Planning (1998), Nancy Hornberger and Kendall King set out to examine the precarious balance that exists between authenticity and unification in the process of standardizing a language. They use Quechua/Quichua in Peru and Ecuador as case studies to understand the various arguments for and against the standardization of the language and the challenges that they continue to face. They define unification as the process of standardizing not only terminology, but also orthography, morphology and syntax. And they define authenticity as a cultivation of both a language's corpus, but also its status within society (Hornberger \& King, 391).

In order to understand the tension between authenticity and unification, Hornberger and King examine the various interest groups involved in the process of standardizing Quechua/Quichua. The greatest obstacle to the standardization of Quechua/Quichua is that in an attempt to unify the language, linguists have also sought to 'purify' it by removing as much Spanish influence as possible (398). This goal is seemingly consistent with the goal of authentication. However, as the unified version reaches native speakers of Quechua, they believe it to be inauthentic in comparison to the regional versions that they learned as children. This addition to the already tense situation further complicates the understanding of what 'authentic' Quechua should look like. The question arises as to which version of the language is more authentic - Unified Quichua ('quichua unificado' in Spanish) which has removed all Spanish influence or authentic Quichua ('quichua auténtico') which is used by native speakers of the language. As Hornberger and King note, "while 'authentic Quichua' reflects the phonological system of the region, it contains many Spanish loan words and has lost some elements of its morphological structure" (403). King found in Ecuador that the standardized 
version of Quichua began gaining dominance as the need for pedagogical materials and instruction grew. However, as Haboud (2004) explains in her analysis of Quichua language vitality in Ecuador, the many varieties of dialectal families created a significant obstacle in the path of standardization (71).

In order to meet the need for bilingual education, the Ministry of Education has established the National Bureau of Intercultural Bilingual Education with the mission to design and develop programs that provide a quality linguistic and cultural education and meets the needs of all peoples of Ecuador. However, it is first necessary to understand the motives of the people to pursue bilingual education for themselves or for their children. When motives are more clearly stated, it is easier to establish clear goals for BIE programs, and thus it is easier to gauge the success or failure of a particular program. Potential goals for the revitalization of Quichua through BIE programs include, among others, 1) to contribute to the preservation of the greater Quichua culture and tradition in the region, 2) to counteract the social stratification that has developed between speakers of Quichua and those of Spanish, and/or 3) to pursue Joshua Fishman's goal of reversing language shift and to save an endangered language. These goals seem to imply that the motivations of students and/or their parents is to prevent the further loss of Quichua in hopes of finding a place for it within the higher social strata. Each of the aforementioned goals calls into question many of the concerns resulting from language standardization.

If the primary intention is to preserve Quichua culture, language planning and bilingual education efforts must consider whether or not the promulgation of Unified Quichua (U.Q.) can realistically achieve that goal. If, as Hornberger and King (1998) found, the older generations who speak Quichua natively or are even Quichua monolinguals do not buy into the authenticity 
of U.Q., can it be said that this standardized version of the language is capable of preserving their culture? Defenders of U.Q. argue that the standardization process eliminated a significant portion of the Spanish influence on the language by removing loan words and Spanish phonetic spellings of Quichua words. However, one can argue that the influence of the Spanish on the indigenous people of Ecuador over the last 500 years has become an intrinsic aspect of their culture. Thus, if U.Q. is not an authentic representation of Quichua culture, it is difficult to imagine that it could successfully preserve their culture.

Similarly, if the intention of teaching Quichua in BIE environments is to combat the social stratification that has occurred between speakers of Quichua and those of Spanish by elevating the position of Quichua in formal environments, the consequences of standardization remain relevant to the conversation. As Hornberger and King (1998) found "such linguistic and communicative division further fragments a linguistic minority community already embattled by Spanish and stifles contact between two groups of speakers" (404). If the introduction and spread of U.Q. only serves to add yet another layer to the socio-linguistic hierarchy that exists in Ecuador, it will fail to achieve the goal of decreasing social stratification based on linguistic division.

This leaves Fishman's reversing language shift as the goal and BIE as the means by which to achieve it. Fishman envisions that reversing language shift (RLS) will be a community effort that "fosters commitment as a type of functional equivalence to kinship among non-kin" (103). In other words, he argues that the kinship ties that bind ethnic groups together are important enough to the concept of a social movement, that it must be involved in the RLS process, despite the demographic developments that resulted from colonialism and created a less homogenous society. He imagines that RLS will include "programmes designed to provide 
social support for families" and intergenerational interaction that will create a greater environment in which the target language can grow and develop (104). Fishman particularly emphasizes that "for RLS success the school must be an integral part of the family-neighborhood axis of child socialization" (105). In this way, his model allows for schools to teach the Unified Quichua that is available in textbooks and other pedagogical materials while the familial and community interaction and support can allow for the use of dialectal Quichua varieties in less formal settings. This alternative is congruent with the recommendation that Hornberger and King (1998) make in their research on authenticity and unification which states that language planners should consider making such a diglossic situation the end goal (407). If this is the case, BIE programs can better balance the dual goals of achieving literacy in Quichua and preserving the culture associated with the language. By adopting U.Q. in schools, standardized teaching materials can be produced and teachers trained in a single version of Quichua that grants the language greater practical usability than a local variety that may create obstacles to communication outside that locality. Moreover, by encouraging the use of local varieties in the community, BIE programs are encouraging students to interact with the older generations that speak those varieties in a manner less formal than the classroom and more consistent with the cultural norms of the area. This contextual language practice with native speakers will only enhance the students' language abilities.

\section{Reversing Language Shift as a Social Movement}

Joshua Fishman (1990) discusses the idea of Reversing Language Shift (RLS) as a social movement that works to pursue a definite goal (in this case the revitalization of a moribund language) in an "enduring and organised" fashion using means outside of 'normal' channels and in opposition to institutional structures (81). Kendall King defines language shift as the study of 
societal level language change (King 2001: 10). Thus, Fishman's theory of RLS is the intentional working to combat language shift in order to maintain the earlier linguistic tradition, calling it specifically "ethnolinguistic persistence."

Fishman's conception of RLS as a social movement necessitates an understanding of the inherently political nature of the issue. He envisions that RLS will be a directing of policy decisions regarding language in order to maintain a culture that intrinsically tied to a language. He makes clear that RLS is not in fear of or in opposition to modernity. He argues that just as change does not necessarily result in chaos; persistence does not necessarily result in equilibrium. His goal is rather to preserve a culture by allowing it to adapt to the times without being overrun by it.

"Experienced RLSers realise that all cultures are constantly changing and that their goal is merely to regulate and direct this change, so that it will not contradict or overpower the core of their cultural system, rather than legislate change out of existence" (85).

Here he acknowledges that RLS is not about legislating a stubborn hold onto a bygone past. However, he believes that language is a marker of cultural division and that the maintenance of such societal boundaries are both a natural result of cultural differentiation as well as a necessary protector of culture from the threat of outsiders (86). The imposition of an outside tongue has for ages been a tool of the colonizer to maintain power and unification in their colonies. It becomes the response of the oppressed to fight, via Fishman's RLS social movement, to defend their language, traditions, and culture. The question becomes whether the social movement is a method by which people can guide governmental policy or if the movement is the reaction to policy, or lack thereof. RLS combines the ideas of language shift as defined above and language planning, which King (2001) defines as the study of efforts to influence the language behavior of 
others (21). Thus, it must be understood how each of these processes functions in order to follow Fishman's guidelines for prioritizing RLS efforts.

Fishman (1990) argues that the ability to successfully reverse language shift is reliant on both intergenerational interaction in the greater social sphere as well as the formal education of the language in schools (104). In McCarty's (2003) research on the revitalization of indigenous languages through bilingual/bicultural education, she found that when "parents and elders were actively involved in pedagogical changes" that teachers and students were empowered to succeed (151). This aligns with Fishman's theory on intergenerational interaction. Family and community support of RLS efforts is necessary for the social movement to succeed. In the case of Navajo among native people of the United States as analyzed by McCarty, parents were able to support their students by using the language at home and in the community. However, in the Ecuadorian Quichua context, the community use may be more difficult to employ as there is a literacy gap in the parent generation. Due to the social stigma attached to Quichua and the lack of formal instruction in the language, there exists a generation of Ecuadorian Quichua peoples who cannot use the language and therefore cannot pass it on their children. For Fishman's theory to function, the eldest generations who are fluent in Quichua will need to get involved in RLS efforts in the community in order to provide the support that McCarty found was invaluable. The next obstacle arises with the dialectical gap that exists between the older generation who use their regional variety of Quichua and the Unified Quichua that students are learning in schools. The hierarchical struggle between the regional and standardized forms of the language must be overcome in order to move forward. If not, there is a risk that Unified Quichua will become nothing more than another level within the hierarchy separating those with formal education and those without. This result would serve to further divide the population 
rather than facilitate their unity as a movement. As with all social movements, there is an inherent power struggle that results from a minority group seeking to make changes to the greater society. As Fishman notes, these groups face the typical obstacle of having to work to convince others that the change for which they are advocating is necessary and correct (101).

The comparison of RLS to asocial movement allows one to envision the process in a way that is more commonly understood as a method of social change. While the ultimate goal of most social movements is to convince the government to change their position on a certain issue, they accomplish this goal by working to change the social consciousness regarding that issue. With regard to RLS, the process of convincing people that it is important to revitalize a language that may have minimal economic or political value can be a significant obstacle. Instead, it seems more pertinent to argue that the language is a necessary component of the culture from which it came and if that culture is to be preserved, the language must be maintained.

In Ecuador, the social movement aspect of language planning and reversing language shift has been led by CONAIE in their mission to advocate for the needs of the indigenous peoples of Ecuador. CONAIE has been at the forefront of political movements concerning indigenous populations since its foundation. In the realm of education, CONAIE served as the voice of the people seeking policy change in support of indigenous education. While indigenous groups being the implementation of community programs for indigenous language education, CONAIE works on the national level to ensure that language policy reflects the desires of the indigenous people (King \& Haboud 2002: 384). In this way, the social movement for BIE is fight for both top-down and bottom-up approaches to language revitalization through education initiatives. As community initiatives grew in number, DINEIB was established as the bridge 
between the indigenous organizations that made up CONAIE and the Ministry of Education (Lopez 2009: 24).

\section{Bilingual Intercultural Education Programs}

In his six-country comparison of bilingual education policy for indigenous groups in Latin America, Luis Lopez (2009) traces the history of BIE in Ecuador to its origins as early as the 1940s when Quichua literacy programs first began to arise. In the decades to follow, Christian non-governmental organizations aided indigenous literacy projects as a part of their evangelizing mission in the region. This process continued until the political and constitutional developments of the 80 s and 90s (22-3). As bilingual and biliteracy efforts moved into the public sphere, more formal pedagogical strategies were applied and models compared to determine the best fit for Ecuador.

The examinations of bilingual intercultural education programs must take in to account not only their efficacy in teaching a language, but also their ability to balance the preservation of the associated indigenous culture and the teaching of other content areas, namely math and science. Because there is a distinction between the economic value of Spanish, math, and science and the symbolic value of Quichua, it would be irresponsible for Ecuador to allow Quichua to harm the education of the other content areas. The questions of identity that relate to a speaker of a language are included in the impetus that encourages the pursuit of bilingual intercultural education. To this end, the potential overlap of history and language arts classes more clearly meets both the cultural and linguistic goals. Students, or their parents, seek out BIE in order to preserve a culture as much as to learn a language. The political evolution of BIE in Ecuador has opened the doors for programs to arise and implement various techniques in pursuit 
of these goals. However, BIE programs must also ensure that students are not falling behind Spanish monolingual students in core content areas.

In her study of bilingual education amongst Navajo speakers in North America, Teresa McCarty (2003) analyzes the utility of bilingual/bicultural education not only in revitalizing the language, but also in preserving an endangered culture. She assumes that "local languages are irreplaceable intellectual, social and cultural resources to their speakers and to humankind." Her underlying premise is based on data that students in schools that operate in a language other than their native language will be much more successful when they are provided with "consistent and cumulative academic support in the native/heritage language" (149). While the students in the Navajo population examined by McCarty differ from the Ecuadorian students in question in that they have a more thorough background in their native language from home use, her analysis of the bilingual programs speaks to the same questions of identity and political power.

\section{King's Ethnography of Communication}

In her ethnographic study, King (2001) used participant observation in two bilingual schools in the Saraguro community of the Loja province in southern Ecuador. From her observations of these schools, she found that while they had differing methodologies for teaching, that neither focused on practical communicative skills beyond basic salutations (158). At the first, more urban school, students had minimal exposure to Quichua outside of the classroom and their ability to produce Quichua in the classroom was limited to basic vocabulary lists and most students were unwilling to produce the language at all (178). In the second, more rural school, students come in with a higher level of Quichua understanding, but the school failed to require them to build upon their skills (181). King acknowledges that these schools were in fact teaching Quichua and the students were demonstrating progress in the language. However, 
this slow and minimal progress does not meet any of the goals of BIE. Without a focus on communicative skills, the students are not gaining practical language abilities that could be used outside the classroom. Furthermore, the learning of basic vocabulary lists that King observed does little to teach students about indigenous culture or other content areas.

King's comparison of schools in rural and urban contexts demonstrates that while the students from a more rural region came in with a better background knowledge of Quichua, they were not necessarily more successful in acquiring the language in the classroom. This would appear to address two concerns about BIE. First, the premise that students without community exposure (i.e. the urban students) will be less successful in learning an indigenous language in the classroom. The students from the rural school may have had a better grasp of the language than the urban students, but their classroom growth was not particularly increased as a result. Second, the premise that students from disadvantaged (i.e. rural) schools will be less successful than their urban counterparts. King's observations did not demonstrate a particular superiority of the more urban school over the rural one. While these two factors may still contribute to the success of BIE programs, they were not the determining factor in the schools visited by King. Further research of the variety conducted by King expanded to encompass more reference points may better reveal the impact of factors other than pedagogical technique.

\section{Standardized Assessments}

A 2005 report from UNESCO on illiteracy and literacy education in Ecuador shows that while the average number of years of schooling is increasing and illiteracy rates are decreasing, the contribution of bilingual schools is dismal, if not detrimental. The report states that the bilingual schools' scores on the standardized assessments at the end of the $5^{\text {th }}$ year are 6.07 and 2.81 out of 20 in Spanish and Mathematics, respectively, compared to 7.78 and 5.42 from the 
Spanish-speaking schools (Lopez 2005:11). These scores demonstrate that not only have the bilingual intercultural schools affected students' achievement in Spanish, which may be a more obvious side-effect, but have also had detrimental effects on content learning. There are a number of factors that may contribute to these deficiencies. First, and most troubling, would be the pedagogical failures of the BIE model and the curricula that arise from it. However, other factors exist including the distribution of BIE schools in rural areas that face their own disadvantages, inadequate teacher preparation, and a lack of funding for bilingual schools.

Regarding these socio-political factors, the report states that rural schools have lower enrollment percentages and lower retention rates than their urban counterparts (11). With the majority of the indigenous population living in rural areas, and therefore their children attending rural schools, it would make sense that BIE exists in these rural areas of the country in order to best serve the appropriate population. Thus, it is possible that the disappointing scores of the bilingual intercultural schools could be correlated to their existence in rural areas. Second, the report states that 40 percent of teachers in the BIE facilities are monolingual (5). Whether they are monolingual in Spanish or Quichua, they are inadequately prepared to teach in a bilingual academic environment and could also contribute to the failures of such schools. Teachers need to be thoroughly trained in the content they teach, the language(s) in which they are to teach, and the pedagogical methods by which they are expected to teach in order to expect positive outcomes from students. And finally, the report reflects the drop in funding for education from $30 \%$ of the national budget in 1980 down to just $12 \%$ in 2002 (5). Of the money allocated for education in 2004, the country spent $\$ 148$ per student in Spanish-speaking primary education and only $\$ 133$ per student in indigenous primary education and this gap in spending increases as students rise into secondary education (12). The lack of funding for education in general as well 
as the unequal distribution of funds between Spanish-speaking and indigenous education could also be a contributing factor in the disparity in student success on the standardized assessments.

\section{Application of Data}

Disregarding the socio-political questions that reach beyond the scope of this research, the questions of the efficacy of the pedagogical models that are being employed in Ecuador are the primary concern. King's (2001) extensive observations of two indigenous schools demonstrate that the techniques employed there are ineffective in securing an ability in the students to function in Quichua. Even the students that had a better grasp on the language did not appear to demonstrate much growth based on the work in the classroom (181). King noted that a significant part of the school day was wasted each day, and that little of the day was devoted to Quichua language (157). From her observations of two very specific instances of bilingual intercultural education combined with the data reported by UNESCO, there is clearly a disconnect between the goals and outcomes of BIE. Ecuador must find a new model that will work better to not only achieve the linguistic goals of those seeking to reverse language shift and preserve Quichua, but also to allow the students to keep up with their Spanish monolingual counterparts in content areas. The subsequent question that emerges is whether it is an inherent fault of the BIE model or a fault in the implementation of the model in the Ecuadorian context.

McCarty (2003) cites a number of programs in North America that take different approaches to the goal of bilingual intercultural education. The most applicable to the linguistic situation of Quichua speakers in Ecuador is research on French immersion programs in Canada. In these programs, monolingual English speakers are placed in a full immersion French school in which they receive all instruction in French for the first few years. Then, English is gradually reintroduced to students and, by $6^{\text {th }}$ grade, the school day is conducted in a 50-50 bilingual 
education environment. The results of this research showed that students were able to learn French without damage done to their English abilities (McCarty 150). Thus, this FrenchCanadian case study supports the belief that BIE can in fact allow students to gain second language competency without suffering any detriment to their first language.

This research is potentially more pertinent to BIE in a Ecuadorian Quichua than it was to McCarty's study of Navajo bilingualism in that the background conditions of the English monolinguals in Canada is more similar to the Spanish monolinguals in Ecuador. McCarty notes that the students who participated in the Canadian program were children whose mother tongue (English) was the language of power but were pursuing another language (French) of relative importance (McCarty 150). In Ecuador, the students who enter school with little to no background in Quichua bring to the classroom a similar perspective to that which the students in the study had. They came to school with a working knowledge of a prestigious global language (Spanish) in pursuit of a language (Quichua) with a different relative value. The primary difference between the two groups lies in the fact that the parents who chose to enroll their children in these programs fully believed in the concrete value of French language skills. However, in Ecuador there is less agreement that the symbolic value of Quichua carries enough consequence to warrant the risks associated with BIE.

In a 2014 MOSEIB report, pedagogical strategies are established and explained that focus on the gradual development of fully bilingual education. The report presents a plan that would begin education 100 percent in the pertinent indigenous language and slowly incorporate more and more Spanish (and a foreign language) until high school students are spending $40 \%$ of their day in their indigenous language, $40 \%$ in Spanish, and $20 \%$ in a foreign language of choice (MOSEIB 2014: 4). This plan would, if actualized, seem to follow the French-Canada model 
discussed by McCarty. Ideally, the similarities in linguistic background would allow for the model used in the Canadian context to serve Ecuadorian BIE programs with comparable success. The goal of such a program would be to have students learning Quichua without damage done to their Spanish abilities.

However, the overarching theme in the research regarding language planning is that those being asked to turn their lives upside down, must buy into the idea that doing so is worth the risk. Fishman (1990) argued that schools were an important aspect of reversing language shift, but that the intergenerational, community support was the backbone of the process and that efforts would not succeed without it. King (2001) comes to the conclusion that successful language planning must "attack the problem from all directions" in the hopes that something strikes to community in a way that convinces them of the need to become masters of their own linguistic fate (228-9). Hornberger and Coronel-Molina (2004) establish that regardless of the language planning tactic employed, that planners bear the burden of proof that the target language "is truly respected by enough people at a high level" in order to convince the people to fight for language revitalization (54).

\section{Conclusions}

"Its future cannot be left to chance: without deliberate intervention and planning... Quechua could still go the way of the many languages already lost" (Hornberger \& Coronel-Molina 2004:54).

The establishment of a constitutional right of linguistic self-determination was a big step for Ecuador in moving out of the a-modal stage, as defined by Fishman, into the uni-modal stage. By offering official, legal recognition to the indigenous languages of Ecuador, the government opened the door to indigenous culture being understood as the unifying identity that was the foundation for uni-modal nations. From there, the country can respond to the will of the people 
to see indigenous languages and cultures preserved and revitalized through public education. However, from the 1981 decree mandating BIE to the 2005 test scores reported by UNESCO, the country has failed to implement programs that succeed in teaching students their indigenous language and the time spent on that language becomes a detriment to their pursuit of Spanish or content areas. While this research would benefit from more current data about standardized assessment result, the results from 2005 point to failures seeming to stem from something other than improper pedagogical strategies. The 2014 MOSEIB report demonstrates that the MEC is aware not only of the techniques that they have tried up until this point, but also of what is working elsewhere. However, the UNESCO report shows that the government is decreasing its funding to education and that the funding that does find its way into schools is not distributed equally between Spanish monolingual and indigenous bilingual schools. Furthermore, teachers at indigenous schools are not receiving the requisite training to accomplish the goals set forth by MOSEIB.

As Fishman (1990) and McCarty (1998) note, while a bigger community picture is crucial to the preservation and revitalization of endangered languages, they both call attention to the reality that schools are an important player in the bigger picture.

"To dismiss schools as insignificant underrates the destructive effect on indigenous languages of past schooling and of current educational practices that neglect those languages; ignores the singular social, economic, and political importance of schools in many American Indian communities; and tosses aside the enormous language-maintenance resources produced by school-based, native language programs"'(McCarty 1998: 28).

As demonstrated by the bilingual education programs analyzed by McCarty, it is possible to achieve the goals that Ecuador has for both indigenous language preservation and academic achievement in Spanish and core content areas. However, without proper funding or teaching training programs, Ecuador will not be successful in their pursuits. If the government were to be 
able to successfully foster the various languages in the country, they could make the leap into the realm of multi-modal nation in which national unity is strong enough to support the existence of multiple cultures and languages. The various language communities could make decisions regarding linguistic education on a regional level that does not interfere with Ecuadorian nationalism.

However, even if the MEC were to more aggressively invest in BIE in order to raise test scores, their efforts will all be for naught without engaged community support of such acquisition planning. If the people are not convinced that the symbolic value of Quichua is sufficient to justify the pursuit of BIE, a top-down government project will not yield the desired results. The government and the people of Ecuador seem to slowly be meeting in the middle. The government has gradually developed BIE and has quite recently, through the MOSEIB report, demonstrated their commitment to a system of education that serves both the cultural and academic needs of the indigenous peoples. On the other side, the pendulum of popular perception of indigenous languages seems to be swinging back in Quichua's favor. If these two groups were to be able to meet in the middle, children in BIE programs could receive both the institutional resources that they need from the MEC and the intergenerational community support that fosters their successful pursuit of Quichua. 


\section{References}

Adelaar, W.F.H. (2004) The languages of the Andes. New York: Cambridge University Press. BBC News. (2014). Ecuador profile. Retrieved from http://www.bbc.com/news/world-latinamerica-19331501.

Burke, K. (1954) Permanence and Change (revised ed.). Los Altos: Hermes

CIA World Factbook (2014). Ecuador country profile. Retrieved from https://www.cia.gov/ library/publications/the-world-factbook/geos/ec.html

CONAIE (1998) Confederatoin of Indigenous Nationalities of Ecuador. HTML document [http://www.conaie.nativeweb.org].

Constitución de la República del Ecuador. (2008). Quito, Ecuador: Asamblea Constituyente.

Fishman, J. A. (1969). National Languages and Languages of Wider Communication in the Developing Nations. Anthropological Linguistics, 11(4), 111-135.

Fishman, J. (1977). 'The spread of English as a new perspective for the study of "language maintenance and language shift"' in J. Fishman et al. (eds.): The Spread of English. Rowley, Mass.: Newbury House Publishers.

Haboud, M. (2004). Quichua language vitality: an Ecuadorian perspective. International Journal of the Sociology of Language, 167, 69-81.

Haboud, M. (2009). Teaching foreign languages: A challenge to Ecuadorian bilingual intercultural education. International Journal of English Studies, 9(1), 63-80.

Hobsbawm, E. (1996). Language, culture, and national identity. Social Research, 63(4), 10651080. 
Hornberger, N. H., \& Coronel-Molina, S. M. (2004). Quechua language shift, maintenance, and revitalization in the Andes: the case for language planning. International Journal of the Sociology of Language, 167, 9-67.

Hornberger, N. H., \& King, K. A. (1998). Authenticity and Unification in Quechua Language Planning. Language, Culture and Curriculum, 11(3), 390-410.

Hornberger, N.H., \& Pütz, M. (Eds.). (2006). Language Loyalty, Language Planning and Language Revitalization: Recent writings and reflections from Joshua Fishman. Buffalo: Multilingual Matters Ltd.

Instituto national de estadistica y censos. (2010). Resultados de Censo 2010. Quito, Ecuador. King, K.A. (2001) Language revitalization processes and prospects: Quichua in the Ecuadorian Andes. Buffalo: Multilingual Matters Ltd.

King, K. A. \& Haboud, M. (2002). Language Planning and Policy in Ecuador. Current Issues in Language Planning, 3(4), 359-424.

Lopez, L. E. (2009). Reaching the unreached: indigenous intercultural bilingual education in Latin America. Paper commissioned for the EFA Global Monitoring Report 2010:

\section{UNESCO.}

McCarty, T. L. (1998). Schooling, resistence, and American Indian languages. International Journal of the Sociology of Language 132, 27-41.

McCarty, T. L. (2003). Revitalising Indigenous Languages in Homogenising Times. Comparative Education, 39(2), 147-163.

Ministerio de Educación del Ecuador. (2014). Modelo del Sistema de Educación Intercultural Bilingüe (Actualización 2014). Quito, Ecuador: Sistema de Educación Intercultural Bilingüe. 
Nettle, D. \& Romaine, S. (2000). Vanishing Voices: the extinction of the world's languages New York: Oxford University Press.

Paul, L. M., Simons, G. F., \& Fennig, C.D. (Eds.). 2015. Ethnologue: Languages of the World, Eighteenth edition. Dallas, Texas: SIL International.

Torres, R.M. (2005). Illiteracy and Literacy Education in Ecuador: Options for Policy and Practice. Fronesis Institute \& UNESCO.

UNESCO (1996). Universal Declaration of Linguistic Rights. Barcelona: World Conference on Linguistic Rights. 